\title{
An Environmentally Friendly Preparation of Iodohydrins from Alkenes Mediated by Clay-Minerals
}

\author{
Raul A. S. Villegas ${ }^{a}$, Mônica R. M. P. de Aguiar ${ }^{*, b}$, Marcio C. S. de Mattos ${ }^{*, a}$, Alcides W. S. Guarino ${ }^{c}$, \\ Lilian M. Barbosa and Luiz Carlos F. N. Assumpção
}

\author{
${ }^{a}$ Instituto de Química, Universidade Federal do Rio de Janeiro, CP 68545, 21945-970 Rio de Janeiro - RJ, Brazil \\ ${ }^{b}$ Instituto de Química, Universidade do Estado do Rio de Janeiro, Rua São Francisco Xavier 524, \\ 20550-01 Rio de Janeiro - RJ, Brazil \\ ${ }^{c}$ Escola de Ciências Biológicas, Universidade do Rio de Janeiro, Av. Pasteur 458, 22290-240 \\ Rio de Janeiro - RJ, Brazil
}

\begin{abstract}
Iodoidrinas são intermediários úteis em síntese orgânica, por exemplo, na obtenção de epóxidos. Aqui é descrita a preparação de iodoidrinas com bons rendimentos, a partir da reação de alquenos (ciclo-hexeno, estireno, $\alpha$-metil-estireno e 1-octeno) com iodo e água, à temperatura ambiente, em presença de argilas ácidas comerciais (K-10 e KSF) e argilas naturais brasileiras (F-101 e F-117), sendo os melhores resultados obtidos com as argilas naturais brasileiras (61-90\%). As análises de DRX das argilas confirmaram tratarem-se de argilominerais do grupo das esmectitas, havendo outros minerais de argila presentes na KSF, K-10 e F-117.
\end{abstract}

\begin{abstract}
Iodohydrins are useful intermediates in organic synthesis for the preparation of epoxides. Herein is reported the preparation of iodohydrins in good yields by the reaction of alkenes (ciclohexene, styrene, $\alpha$-methylstyrene, and 1-octene) with iodine and water at room temperature, in presence of acid commercial clays (K-10 and KSF) and natural Brazilian clays (F-101 and F-117), being the best results obtained with Brazilian clays (61-90\%). The XRD results confirmed that the clays belong to the smectite clay-mineral group and K-10, KSF and F-117 have other clay-minerals in their structures.
\end{abstract}

Keywords: iodohydrins, clay-minerals, green chemistry, alkenes, eletrophilic addition

\section{Introduction}

Chloro- and bromohydrins can be prepared in good yields when the halogenation of the alkene is carried out in aqueous media. ${ }^{1}$ On the other hand, the preparation of iodohydrins (an alternate and efficient epoxide precursor ${ }^{2}$ ) from the reaction of alkenes with $\mathrm{I}_{2} / \mathrm{H}_{2} \mathrm{O}$ is difficult due to the reversibility of the addition of iodine to the double bond, and an iodide ion scavenger (a metal salt or an oxidizing reagent) is needed to obtain satisfactory yields. ${ }^{3}$ Other methodologies include reaction of alkenes with $\mathrm{HIO}_{4} \cdot 2 \mathrm{H}_{2} \mathrm{O} / \mathrm{NaHSO}_{3},{ }^{3} \mathrm{~N}$-iodoimides, ${ }^{3} \mathrm{~N}$-iodosaccharin, ${ }^{3}$ bis(piridine)iodine(I) salts, ${ }^{3}$ dimethydioxirane/MeI, ${ }^{4}$ and triiodide ion ${ }^{5}$ in aqueous media. Recently, Wakharkar and co-workers published the preparation of iodohydrins by the reaction of styrene and indene with $\mathrm{I}_{2} / \mathrm{H}_{2} \mathrm{O}$ mediated by EPZ- $10^{\circledR}$ (a commercial clayzinc prepared from montmorillonite and $\mathrm{ZnCl}_{2}$ ).

\footnotetext{
*e-mail: mmarques@uerj.br; mmattos@iq.ufrj.br
}

Clay-minerals are silicates of aluminium with layered structure that present a wide use in organic synthesis ${ }^{7}$ and exhibit specific features such as high versatility, gain in yield and/or selectivity, low cost etc. ${ }^{8}$ Among the several groups of clay-minerals, the smectites are the most useful in organic reactions. Their structure is characterized by presence of an octahedral alumina layer between two tetrahedrical silicate layers.

Herein we communicate our initial results on the reaction of representative alkenes (ciclohexene, 1-octene, styrene, and $\alpha$-methylstyrene) with $\mathrm{I}_{2} / \mathrm{H}_{2} \mathrm{O}$ in the presence of commonly used commercial acid-treated clays (K-10 or KSF) and natural Brazilian clays (F-101 or F-117).

\section{Experimental}

\section{General}

All chemicals were used without further purification. K-10 and KSF were purchased from Aldrich. F-101 and F-117 were donated by "Bentonit do Brasil" (Brazilian 
Co.). Analysis by HRGC were performed on a HP-5890-II gas chromatograph with FID by using a $30 \mathrm{~m}$ (length), $0.25 \mathrm{~mm}$ (ID) and $25 \mu \mathrm{m}$ (phase thickness) RTX-5 silica capillary column and $\mathrm{He}$ (flow rate $50 \mathrm{~cm} \mathrm{~s}^{-1}$ ) as carrier gas (split 1:20). Mass spectra were obtained on a HewlettPackard HP5896-A HRGC-MS using electron impact (70 eV). ${ }^{1} \mathrm{H}$ NMR and ${ }^{13} \mathrm{C}$ NMR were acquired on a Bruker DRX-300 (300 MHz and $75 \mathrm{MHz}$, respectively) or on a Bruker AC-200 (200 MHz and $50 \mathrm{MHz}$, respectively) spectrometers for $\mathrm{CDCl}_{3}$ solutions with tetramethylsilane as internal standard. IR spectra were recorded on a Perkin Elmer 1600 FT-IR or on a Nicolet 740 FT-IR spectrometers ( $\mathrm{NaCl}$ film). XRD analysis of oriented fractions were made using a Rigaku-Geigerflex 2013 diffractometer equipped with a proportional counter and pulse height analyser using $\mathrm{Ni}$ filtered $\mathrm{CuKa}$ radiation, produced under conditions of $40 \mathrm{kV}$ and $30 \mathrm{~mA}$. Diffraction patterns were collected at a scanning rate of $4^{\circ}(2 \theta) / \mathrm{min}$ in the interval of $2^{\circ}$ and $30^{\circ}$.

\section{Typical procedure for iodohydrin formation}

To a stirred suspension of the appropriate alkene ( 5 $\mathrm{mmol})$ and the clay $(1 \mathrm{~g})$ in 1,4-dioxane $\left(15 \mathrm{~cm}^{3}\right)$ and water $\left(2 \mathrm{~cm}^{3}\right)$, it was added iodine $(10 \mathrm{mmol})$ in small portions at room temperature. After $24 \mathrm{~h}$, the clay was filtered off, $\mathrm{CHCl}_{3}\left(20 \mathrm{~cm}^{3}\right)$ was added and the organic layer was washed with a saturated solution of $\mathrm{Na}_{2} \mathrm{~S}_{2} \mathrm{O}_{3}\left(3 \times 5 \mathrm{~cm}^{3}\right)$ and brine $\left(5 \mathrm{~cm}^{3}\right)$. The organic extract was dried (anhydrous $\mathrm{Na}_{2} \mathrm{SO}_{4}$ ) and filteres trough a small column of $\mathrm{SiO}_{2}$. The solvent was evaporated on a rotatory evaporator and then concentrated under reduced pressure $(267 \mathrm{~Pa})$ and $50{ }^{\circ} \mathrm{C}$ (bath) to give the pure iodohydrin as a colorless or light orange oil. The analytical data for the iodohydrins are in accordance with those previously reported. ${ }^{2}$

\section{trans-2-Iodocyclohexanol}

${ }^{1} \mathrm{H}$ NMR $\delta$ 1.25-1.55 (m, 4H); 1.79-1.81 (m, 2H); 1.99$2.07(\mathrm{~m}, 2 \mathrm{H}) ; 2.65($ broad s, 1H, OH); 3.64 (m, 1H); 3.99$4.03\left(\mathrm{~m}, 1 \mathrm{H}, J_{\mathrm{CHI}-\mathrm{CHOH}} 9.7 \mathrm{~Hz}\right) \mathrm{ppm} .{ }^{13} \mathrm{C} \mathrm{NMR} \delta 24.2 ; 27.7$; $33.5 ; 38.3 ; 42.9 ; 75.6$ ppm. IR ( NaCl film) $v_{\max } / \mathrm{cm}^{-1}: 3380$; 2920; 2840; 1440; 1350; 1150; 1060; 940. MS $m / z$ (\%) 81 (100); 99; 127; 141; 155; 170; 180; $226\left(\mathrm{M}^{+}, 5\right)$.

\section{2-Iodo-1-phenylethanol}

${ }^{1} \mathrm{HNMR} \delta 2.80(\mathrm{~d}, 1 \mathrm{H}, \mathrm{OH}, \mathrm{J} 4.4 \mathrm{~Hz}) ; 3.36-3.51(\mathrm{~m}, 2 \mathrm{H}) ;$ 4.81-4.84 (m, 1H); $7.36(\mathrm{~m}, 5 \mathrm{H}) \mathrm{ppm} .{ }^{13} \mathrm{C} \mathrm{NMR} \delta 15.3 ; 73.8$; $125.6 ; 128.2 ; 128.5 ; 141.1 \mathrm{ppm}$. IR (NaCl film) $v_{\max } / \mathrm{cm}^{-1}$ : 3410 (broad); 3029; 2956; 2892; 1175; 1055; 845; 764; 700. MS m/z (\%) $81(100) ; 121 ; 217 ; 231 ; 248\left(\mathrm{M}^{+}, 40\right)$.

\section{1-Iodo-2-phenyl-2-propanol}

${ }^{1} \mathrm{H}$ NMR $\delta 1.74(\mathrm{~s}, 3 \mathrm{H}) ; 2.45($ broad s, $1 \mathrm{H}, \mathrm{OH}) ; 3.65(\mathrm{~d}$, $2 \mathrm{H}, J 3.2 \mathrm{~Hz}) ; 7.36(\mathrm{~m}, 5 \mathrm{H}) \mathrm{ppm} .{ }^{13} \mathrm{C} \mathrm{NMR} \delta 24.0 ; 28.8$; $66.9 ; 124.5 ; 127.3 ; 128.3 ; 141.1$ ppm. IR ( $\mathrm{NaCl}$ film) $v_{\max } / \mathrm{cm}^{-1}: 3530$ (broad); 3057; 3024; 2957; 2929; 2891; $1275 ; 1168 ; 1030 ; 849 ; 780 ; 700$. MS m/z (\%) 121 (100); 135; 169; 204; 244; $262\left(\mathrm{M}^{+}, 5\right)$.

\section{1-Iodo-2-octanol}

${ }^{1} \mathrm{H}$ NMR $\delta 0.90(\mathrm{t}, 3 \mathrm{H}) ; 1.26-1.54(\mathrm{~m}, 8 \mathrm{H}) ; 2.00($ broad s, $1 \mathrm{H}, \mathrm{OH}) ; 3.24(\mathrm{dd}, 1 \mathrm{H}, J 11.0$ and $7.0 \mathrm{~Hz}) ; 3.41(\mathrm{dd}, 1 \mathrm{H}$, $J 11.0$ and $3.2 \mathrm{~Hz}) ; 3.50-3.53(\mathrm{t}, 3 \mathrm{H}) \mathrm{ppm} .{ }^{13} \mathrm{C} \mathrm{NMR} \delta 14.1$; $16.3 ; 22.5 ; 25.4 ; 29.1 ; 31.7 ; 36.5 ; 71.0$ ppm. IR $(\mathrm{NaCl}$ film) $v_{\max } / \mathrm{cm}^{-1}: 3370$ (broad); 2970; 2940; 2860; 1470; $1420 ; 1380 ; 1180 ; 1120 ; 1025$. MS $m / z$ (\%) 44; 129 (100); $171 ; 256\left(\mathrm{M}^{+}, 5\right)$.

\section{Results}

The results of the reaction of the alkenes with $I_{2}$ in aqueous 1,4-dioxane in the presence of diverse clays are summarized in Scheme 1 and Table 1.

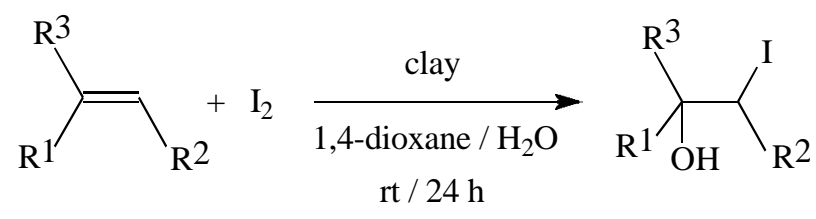

Scheme 1.

Table 1. Yields of iodohydrins according to Scheme 1

\begin{tabular}{|c|c|c|c|c|}
\hline Clay & $\mathrm{R}^{1}$ & $\mathrm{R}^{2}$ & $\mathrm{R}^{3}$ & Yield $^{\mathrm{a}}(\%)$ \\
\hline \multirow[t]{4}{*}{$\mathrm{K}-10$} & \multicolumn{2}{|c|}{$-\left(\mathrm{CH}_{2}\right)_{4}-$} & $\mathrm{H}$ & $72^{\mathrm{b}}$ \\
\hline & Hex & $\mathrm{H}$ & $\mathrm{H}$ & $55^{\mathrm{c}}$ \\
\hline & $\mathrm{Ph}$ & $\mathrm{H}$ & $\mathrm{H}$ & 63 \\
\hline & $\mathrm{Ph}$ & $\mathrm{H}$ & $\mathrm{Me}$ & 68 \\
\hline \multirow[t]{4}{*}{ KSF } & \multicolumn{2}{|c|}{$-\left(\mathrm{CH}_{2}\right)_{4}-$} & $\mathrm{H}$ & $79^{\mathrm{b}}$ \\
\hline & Hex & $\mathrm{H}$ & $\mathrm{H}$ & $49^{c}$ \\
\hline & $\mathrm{Ph}$ & $\mathrm{H}$ & $\mathrm{H}$ & 41 \\
\hline & $\mathrm{Ph}$ & $\mathrm{H}$ & $\mathrm{Me}$ & 45 \\
\hline \multirow[t]{4}{*}{ F-117 } & \multicolumn{2}{|c|}{$-\left(\mathrm{CH}_{2}\right)_{4}-$} & $\mathrm{H}$ & $86^{\mathrm{b}}$ \\
\hline & Hex & $\mathrm{H}$ & $\mathrm{H}$ & $61^{\mathrm{c}}$ \\
\hline & $\mathrm{Ph}$ & $\mathrm{H}$ & $\mathrm{H}$ & 66 \\
\hline & $\mathrm{Ph}$ & $\mathrm{H}$ & $\mathrm{Me}$ & 64 \\
\hline \multirow[t]{4}{*}{ F-101 } & \multicolumn{2}{|c|}{$-\left(\mathrm{CH}_{2}\right)_{4}-$} & $\mathrm{H}$ & $90^{\mathrm{b}}$ \\
\hline & Hex & $\mathrm{H}$ & $\mathrm{H}$ & $66^{\mathrm{c}}$ \\
\hline & $\mathrm{Ph}$ & $\mathrm{H}$ & $\mathrm{H}$ & 67 \\
\hline & $\mathrm{Ph}$ & $\mathrm{H}$ & $\mathrm{Me}$ & 78 \\
\hline- & \multicolumn{2}{|c|}{$-\left(\mathrm{CH}_{2}\right)_{4}-$} & $\mathrm{H}$ & $28^{\mathrm{b}, \mathrm{d}}$ \\
\hline
\end{tabular}

${ }^{\mathrm{a}}$ Yield of pure iodohydrin based on alkene; ${ }^{\mathrm{b}}$ trans-Product; ${ }^{\mathrm{c}}$ Obtained predominatly with 2-iodo-1-octanol (ca. $4: 1$ by HRGC); ${ }^{\mathrm{d} A f t e r} 12$ days. 
The reactions were carried out at room temperature by stirring together a suspension of the clay and the appropriate alkene in 1,4-dioxane, water and iodine for $24 \mathrm{~h}$. Analysis of the crude reaction mixture by high-resolution gas chromatography (HRGC) showed the formation of a single iodohydrin (the products were confirmed by coinjection in HRGC with authentic samples prepared as described ${ }^{2}$ ). Exception was observed with 1-octene only that gave both regioisomeric iodohydrins (the secondary alcohol predominated by $4.5: 1$ ). It was observed that the best results were obtained with natural Brazilian clays (F-101 and F-117), and in the absence of any clay the reaction of cyclohexene led to the iodohydrin in only $28 \%$ yield after 12 days.

Figure 1 shows the XRD patterns obtained for the clay samples. The diffractogram of all clays exhibited a peak at $2 \theta=6.0^{\circ}(14.7 \AA)$, corresponding to the 001 plane of the smectite clay-mineral group. As the Brazilian clays F-101 and F-117 belong to the same region of other clays studied in the literature, ${ }^{9}$ the 001 peak related indicates the presence of smectite group (S). All clays showed a strong reflection corresponding to $3.33 \AA\left(2 \theta=26.7^{\circ}\right)$ and a minor one at $3.25 \AA\left(2 \theta=27.4^{\circ}\right)$, suggesting that quartz $(\mathrm{Q})$ was the predominant mineral in them. ${ }^{9}$ The $\mathrm{K}-10$ and $\mathrm{F}-117$ clays also have others clay minerals: K-10 has mica, KSF has kaolite and F-117 has both mica and kaolinite. The 001 peak was very broad in KSF. The smectite reflection appears at $2 \theta=21.4^{\circ}$, suggesting a $\mathrm{d}(003)$ reflection. The corresponding clay-mineral peak of a smectite group was more pronounced in the natural clays than in the acid clays, suggesting that the previous acid treatment of KSF and K-10 disarranges the smectite structure. ${ }^{10,11}$ These facts show the importance of the clay-mineral structure to the formation of the iodohydrins, once the better yields were obtained with the natural Brazilian clays.

In summary, we have developed a simple methodology to prepare iodohydrins from alkenes in mild conditions, good yields and high purity. Considering the environmental issues that require the substitution of toxic catalysts by more friendly solid catalysts, and the advantages of heterogeneous catalysis in terms of ease of work up, our methodology is consistent with Green Chemistry philosophy. ${ }^{12}$

\section{Aknowledgements}

We would like to thank "Bentonit do Brasil" for the kindly samples donation of F-101 and F-117 clays, CNPq and FAPERJ for financial support. Raul A.S. Villegas thanks CAPES, Lilian M. Barbosa and Luiz Carlos F.N. Assumpção thank Cetreina/UERJ for fellowships.
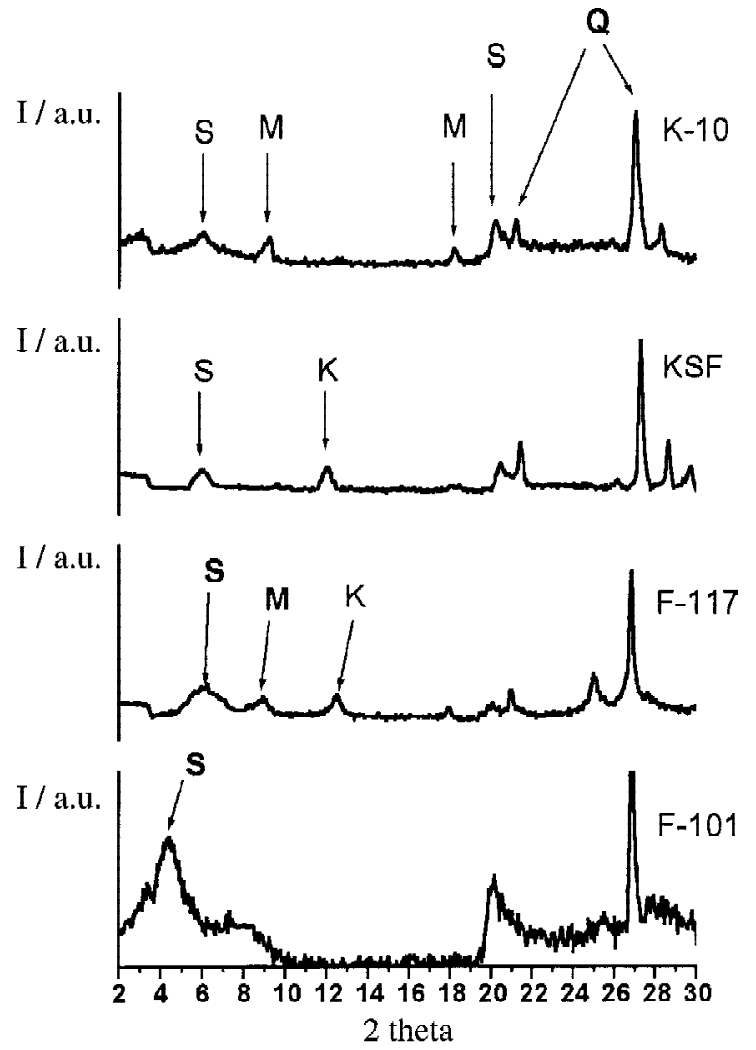

Figure 1. DRX patterns of the studied clays ( $\mathrm{S}=$ smectite; $\mathrm{M}=$ mica; $\mathrm{K}=$ kaolinite; $\mathrm{Q}=$ quartz).

\section{References}

1. Cornforth, J. W.; Green D. T.; J. Chem. Soc. C 1970, 846.

2. Sanseverino, A. M.; de Mattos, M. C. S.; Synth. Commun. 1998, 28, 559 .

3. De Mattos, M. C. S.; Sanseverino, A. M.; J. Chem. Res. (S) 1994, 440.

4. Sanseverino, A. M.; da Silva, F. M.; Jones Jr., J. ; de Mattos, M. C. S.; Quim. Nova 2001, 24, 637.

5. Sanseverino, A. M.; de Mattos, M. C. S.; Synthesis 1998, 1584.

6. Mahajan, V. A.; Shinde, P. D.; Gajare, A. G.; Karthikeyan, M.; Wakharkar, R. D.; Green Chem. 2002, 4, 325.

7. Varma, R. S.; Tetrahedron 2002, 58, 1235.

8. Vaccari, A. V.; Appl. Clay Sci. 1999, 14, 161.

9. Guarino, A. W. S.; San Gil, R. A.; Polivanov, H.; Menezes, S. M. C.; J. Braz. Chem. Soc. 1997, 8, 581

10. Kumar, P.; Jasra, R. V.; Bhat, T. S. G.; Ind. Eng. Chem. Res. 1995, 34, 1440.

11. Komadel, P.; Schmidt, D.; Madejova, J.; Cicel, B.; Appl. Clay Sci. 1990, 5, 113.

12. Anastas, P. T.; Warner, J. C.; Green Chemistry: Theory and Practice, Oxford University Press: Oxford, 2000.

Received: January 27, 2003

Published on the web: November 28, 2003 